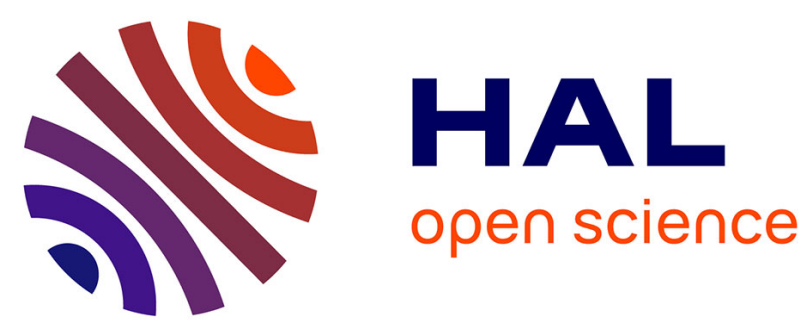

\title{
Spectrotemporal dynamics of a picosecond OPO based on chirped quasi-phase-matching: erratum
}

Delphine Descloux, Cédric Laporte, Jean-Baptiste Dherbecourt, Jean-Michel Melkonian, Myriam Raybaut, Cyril Drag, Antoine Godard

\section{To cite this version:}

Delphine Descloux, Cédric Laporte, Jean-Baptiste Dherbecourt, Jean-Michel Melkonian, Myriam Raybaut, et al.. Spectrotemporal dynamics of a picosecond OPO based on chirped quasi-phase-matching: erratum. Optics Letters, 2017, 43 (3), page 494. 10.1364/OL.43.000494 . hal-01705368

\section{HAL Id: hal-01705368 \\ https://hal.science/hal-01705368}

Submitted on 21 Feb 2018

HAL is a multi-disciplinary open access archive for the deposit and dissemination of scientific research documents, whether they are published or not. The documents may come from teaching and research institutions in France or abroad, or from public or private research centers.
L'archive ouverte pluridisciplinaire HAL, est destinée au dépôt et à la diffusion de documents scientifiques de niveau recherche, publiés ou non, émanant des établissements d'enseignement et de recherche français ou étrangers, des laboratoires publics ou privés. 


\title{
Optics Letters
}

\section{Spectrotemporal dynamics of a picosecond OPO based on chirped quasi-phase-matching: erratum}

\author{
Delphine Descloux, ${ }^{1}$ Cédric Laporte, ${ }^{1}$ Jean-Baptiste Dherbecourt, ${ }^{1}$ Jean-Michel Melkonian, ${ }^{1}$ \\ Myriam Raybaut, ${ }^{1}$ Cyril Drag, ${ }^{2}$ and Antoine Godard ${ }^{1, *}$ (i) \\ 'ONERA-The French Aerospace Lab, F-91123 Palaiseau cedex, France \\ ${ }^{2}$ Laboratoire Aimé-Cotton, CNRS, Univ. Paris-Sud, ENS Cachan, Université Paris-Saclay, F-91405 Orsay cedex, France \\ *Corresponding author: antoine.godard@onera.fr
}

Received 22 December 2017; posted 23 December 2017 (Doc. ID 318137); published 25 January 2018

This erratum is to correct an error made in our paper [Opt. Lett. 40, 280 (2015)] regarding the sign of the quasi-phase matching chirp rate. () 2018 Optical Society of America

OCIS codes: (190.4970) Parametric oscillators and amplifiers; (190.7110) Ultrafast nonlinear optics; (140.4050) Mode-locked lasers; (190.4410) Nonlinear optics, parametric processes.

https://doi.org/10.1364/OL.43.000494

We have found that the actual sign of the quasi-phase matching $(\mathrm{QPM})$ chirp rate $\kappa^{\prime}(z)$ involved in the reported experiments and simulations was opposite to the one considered in the Letter. Correct Eq. (1) must thus read:

$$
\kappa^{\prime}(z)=\frac{d K_{g}(z)}{d z} .
$$

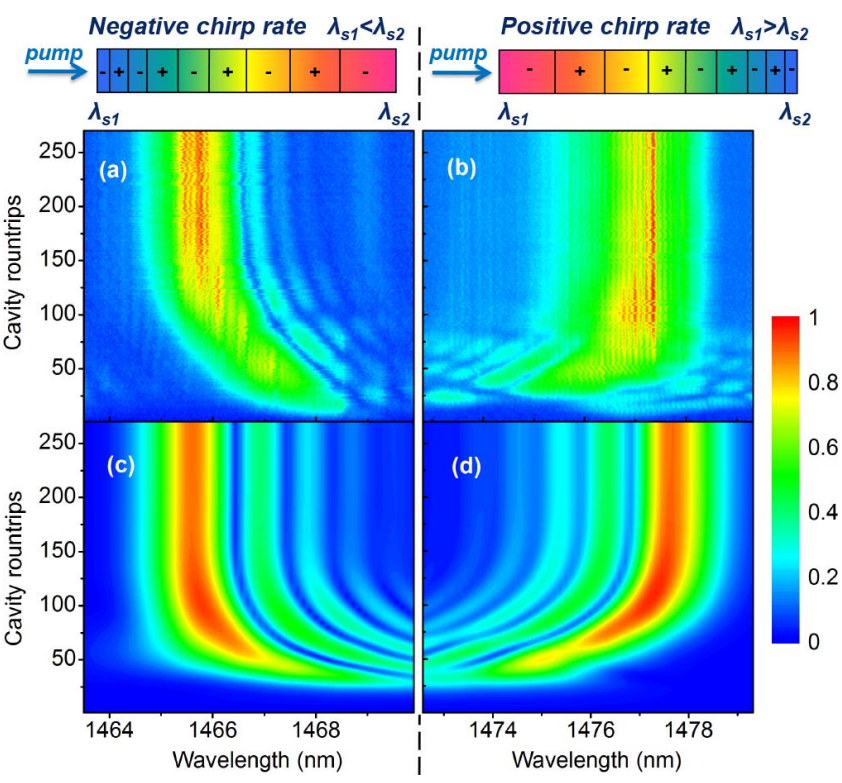

Fig. 1. Corrected version of Fig. 3 from [1] with the proper definition Eq. (1) of the QPM chirp rate $\kappa^{\prime}(z)$ in the upper diagrams.
In Fig. 3 of [1], the schematic diagrams that illustrate negative and positive chirp rates must be swapped as shown in Fig. 1 which is its corrected version.

Conversely to what is stated in [1], the wavelengths that are quasi-phase matched in the input end of the crystal are thus actually favored in strong signal regime. This behavior could be attributed to the depletion of the pump pulse occurring from the input of the crystal, which reduces the gain at the other wavelengths amplified along the remaining of the QPM grating. For numerical modeling of these effects, one has to consider the whole signal spectrum. Hence, the single-pass gain spectra, calculated varying the central wavelength of narrowband signal pulses (5 ps duration with a Fourier transform limited linewidth of $0.64 \mathrm{~nm}$ ) and shown in Fig. 4 of [1], did not contain the overall physical picture. The short discussion in the second column of p. 282 (second paragraph) of [1], based on the analysis of these single-pass gain spectra to explain the influence of the QPM chirp sign, must thus be reconsidered accordingly.

Except these minor points, all the remaining of the paper remains valid using the proper definition Eq. (1) of QPM chirp rate $\kappa^{\prime}(z)$.

\section{REFERENCES}

1. D. Descloux, C. Laporte, J. B. Dherbecourt, J. M. Melkonian, M. Raybaut, C. Drag, and A. Godard, Opt. Lett. 40, 280 (2015). 